\title{
Environmental Footprint Assessment of Educational Campus in South India from a Food- Water-Energy Nexus Perspective
}

\author{
Dr.J.S.Sudarsan , V. Srihari, Jaisal D, Jyesta W
}

\begin{abstract}
The increasing population and progress in technology has led to a haphazard and limitless use of energy resources. This has taken our earth by a toll due to imbalance in the ecological cycle. In the contest to find alternatives to non-renewable resources, the importance of the renewable resources is not properly studied which results in their indiscriminate utilization. Also, it leads to the exhaustion of these abundantly available resources which sadly, cannot be renewed and replaced immediately. The ecological footprint is a resource management tool that measures, in terms of equivalent area global hectares per capita (GHA), how much land and water a given population requires for its current way of life. It also measures the area needed to produce the resources a population consumes and to absorb its wastes. Calculation of the ecological footprint gives an idea about the sustainability and lifestyle practices It has been estimated for a few cities and even countries around the world. Here, we determine the ecological footprint of the educational institute located in south India. Knowing the footprint of an educational institute's campus will help to plan for a sustainable future for the generations to come.
\end{abstract}

Keywords: Ecological footprint, green campus, sustainable development.

\section{INTRODUCTION}

$T_{\text {he indiscriminate and injudicious use of renewable }}$ resources by man has led to large-scale misuse of valuable resources including air, soil, land and water. More harm is done to the Earth because of this resource use because in the race to find alternatives to non-renewable resources. Due to this the renewable resources are slowly getting damaged and some of the resources like groundwater getting extinct in many parts of the country. The ecological footprint is a resource management tool that measures, in terms of equivalent area, (global hectares per capita - GHA) how much land and water a given population requires for its current way of life. The ecological footprint also measures the area needed

Revised Manuscript Received on December 05, 2019.

Dr.J.S.Sudarsan ,AssistantProfessor,NICMAR,25/1,NIA,Post Off, Balewadi, Pune 411045. Email: sudarsanjss@ gmail.com

DrV.Srihari , Professor, NICMAR Jagganguda, Aliabad Post Hyderabad500101. Email: vsrihari@nicmar.ac.in

Jaisal D, PGPACM, NICMAR, 25/1, NIA, Post Off, Balewadi, Pune 411045. Email: jaisaldal@ gmail.com

Jyesta W, PGPACM, NICMAR, 25/1, NIA, Post Off, Balewadi, Pune 41104, Email: jyestawalikar@gmail.com to produce the resources a population consumes and to absorb its wastes.

In this research study, Initiative was carried out to explore the ecological footprint, and thus the sustainability, of educational institutional campus in South India. The educational institution campus consists of several Departments/Schools, hospital, and hostels, the engineering schools and campus and the hostels cover the major part of the educational institutional campus and the same were considered for this study [Fig. 1]. The total area taken up for the study is thus about 17 acres.

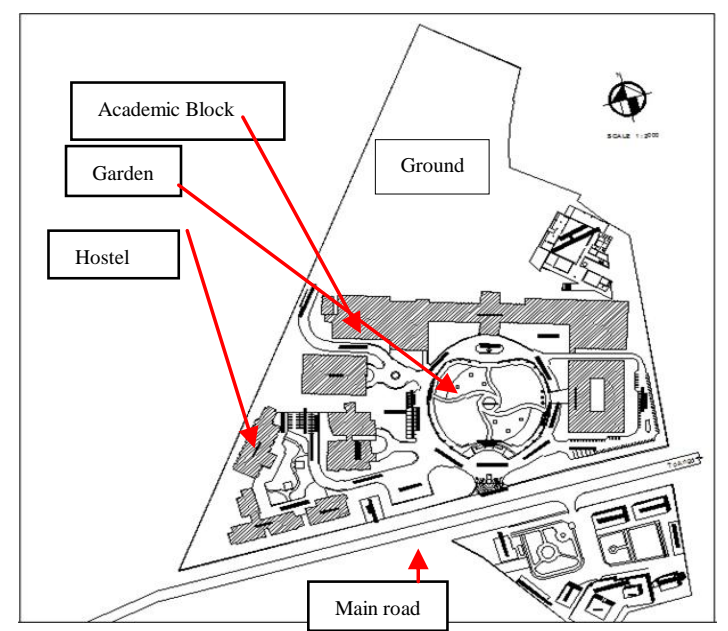

Fig. 1.Layout of Educational institution

\section{ECOLOGICAL FOOTPRINT ANALYSIS}

The idea of ecological footprint analysis was established in the mid-1990s by William Rees and Mathis Wackernagel at the University of BC in Vancouver, Canada. The fundamental idea of the ecological footprint study is the observation that within a certain period of time all consumption of energy and materials, and all discharge of wastes require a finite amount of land and water area for resource making and waste absorption [1]. In the analysis, the resources used up for all types of consumption are listed and valued. The resources are divided into transport, water, energy etc. depending on the nature of the calculations considered. These values are then converted into corresponding land usages. The subsequent per capita footprint thus calculated is equated to the worldwide Earth-share, which is the average land accessibility per person on earth [2]. 
In 2016, the average per capita footprint for the entire world was about 2.75 global hectares [GHA] per capita approximately 22.6 billion in total. The ecological foot prints of the developed countries are estimated as Australia 9.31, USA 8.22, Canada 8.17, and UK 7.93. US footprint per capita was 8.22 GHA, and China's was 3.38 GHA [3]. According to the Global Footprint Network [GFN], we have already overshot the bio capacity of the planet by 25\% [4]. Wackernagel and Ritik [2000] estimated that the available biological capacity for 6 billion people on Earth was about 1.3 hectares per person in 1996 [3]. But they did not consider some productive areas such as marine regions. India's per capita footprint is $0.8 \mathrm{GHA}$ in the year 2003 and the same increased to 1.16 in the year 2016, even though there is slight increase in the foot print during the last 15years if you compare the same to the global average it is quite lower. But India's biocapacity is an alarmingly low 0.4 GHA [5]. The biocapacity of India has been steadily decreasing whereas the footprint has not. Also, the fast pace of growth in India in the last 20 years, the footprints of urban and rural India seems to be varied widely.

The ecological footprint analysis can be considered to be one of the indicators of sustainability and can also be compared to the life cycle analysis [LCA] of a product. However, some criticisms remain with this method. It is considered to oversimplify the measurement of sustainability, and also provides a single value that makes it difficult to understand where the major resource consumption lies. Some modifications have been made to the analysis for use in a larger context [6] [17].

\section{RESULTS AND DISCUSSIONS}

As per the above discussion, a suitable method for analyzing the ecological footprint of an institutional building is acknowledged and adopted. The main inventories responsible for the ecological footprint were identified and the respective data was collected. The calculations were carried out as follows and recorded.

\section{Calculation of ecological footprint for Educational} Institutional campus

Several universities in the US have already initiated drives to become "green campuses". Ecological footprint calculations have been undertaken as part of this measure in campuses such as MIT, University of Redlands, University of Minnesota, Rutgers University and Colorado College, to name a few [7-10]. It was decided to calculate the ecological footprint of Educational Institution located in south India in this study to obtain an understanding of the resource use of a typical campus in South India. Educational Institution has one of the oldest and largest private campuses in the south India. The calculation of the footprint will enable the consequent reduction of waste and speed up a move towards sustainability. This is imperative because universities in India have to take the lead now and show the way for a sustainable future for the country.

The engineering campus of Educational Institution and the hostels were considered in this initial assessment. Electricity, food, transportation and water data were collected from college utilities. Electricity consumption was obtained from the maintenance department. Food data were acquired from the food storage department. Fuel consumption details were acquired from the transportation department. Water details were acquired from the maintenance department. All the data except food were collected for the academic year 2016-2017 or for the available number of months and converted to annual values. Food data were collected for only nine months as the hostels are closed for vacation for almost three months.

The data obtained from the sources mentioned above and utilized in the ecological footprint calculation are shown in Table I [11] [16].

Table- I: Emission through various factors in the Institutional Campus

\begin{tabular}{|c|c|}
\hline Components & $\begin{array}{c}\text { Total amount } \\
\text { consumed }\end{array}$ \\
\hline Electricity & $29,01,265 \mathrm{kWh}$ \\
\hline Diesel Fuel & $1,84,290$ liters \\
\hline Food & $60,00,000 \mathrm{~kg}$ \\
\hline Water & $10,00,20,890$ liters \\
\hline
\end{tabular}

\section{Analysis of individual components}

\section{A. Energy}

In 2016-2017, Educational Institution used 29, 01,265 kilowatt hours $(\mathrm{kWh})$ for the power supply in the engineering and hostel buildings. The energy comes from six coal-burning power plants. The plants function at an average efficiency of $60 \%$, and consume lignite coal which has a heat content of about 18.01 kilojoules $(\mathrm{kJ})$ per gram, and is eighty-five percent carbons by mass. The conversion of energy into equivalent land results in an energy footprint of 530 ha approximately.

\section{B. Transportation}

Many of the students and most faculty members of the college travel from the nearest city of Chennai, an average distance of $50 \mathrm{~km}$ one-way. The university operates a fleet of buses to and from the city. In addition, there are other vehicles such as vans and cars operating within the campus. In the time period of analysis, 1, 84,290 liters of diesel fuel was consumed for transportation purposes. Diesel produces about 138,700 BTU per gallon, and releases 19.95 metric tons of carbon per billion BTU. By converting the volume of diesel fuel into tons of carbon and by using the conversion factor provided by Wackernagel and Ritik [2000] of 1 hectare per 1.8 metric tons of carbon [10], 
the footprint for transportation results as 78 ha approximately. It has to be borne in mind that this value does not consider other factors impacting the transportation footprint. These include daily railway travel by students, movement of hostel students in weekends and evenings, and travel by road/rail/air during vacation and other hidden factors. These factors, when included, are likely to increase the transportation footprint.

\section{Water}

The water use comprises the usage in the college premises, canteens and hostels. Gardening also accounts for some portion of the water use. In 2016-2017, the total water consumption was $10,00,20,890$ liters. The water consumption in the college premises was $10,000 \mathrm{lpd}$ of potable water and $75,000 \mathrm{lpd}$ of non-potable water. The quantity of water consumed is converted into a land value by using a conversion factor of 0.08 hectares of land per million liters of water consumed [12]. The land equivalent turns out to be 7.2 ha for the consumption of water.

\section{Food}

There are 18 hostels in the campus with a total resident student population of about 10000 . Approximately 60,00,000 $\mathrm{kg}$ of food including rice, vegetables, fruits and processed food is consumed by the students over a 9-month period. This

value also includes the quantity of food from the two canteens on campus. The conversion of food into equivalent land has been done by using the Excel spreadsheet provided by Wackernagel [13]. This spreadsheet converts the different categories of food items into corresponding land usages according to the sources. For example, the amount of fish consumed takes into account the marine area required for the catch. The various land categories are cultivable land, grassland, forest, built-up land and sea and also the factors such as the percentage of food that is wasted regularly and the amount of processed food consumed are also considered. The per capita footprint for the food for the population taken in this study turns out to be 3 ha approximately.

\section{Discussion}

Table-II shows the total footprint, per capita footprint and percentage of overall consumption for the Educational Institutional campus [11].

The calculation of the footprints and the resulting table throw some interesting results. The advantages and disadvantages of the campus setting are clearly visualized.

The very small footprint for campus area is the result of the temporary nature of life inside the campus i.e.- if we were to consider the extended footprints of the residences of students and faculty members, we will definitely end up with a larger footprint. Energy and diesel fuel account for about 0.1 ha per capita. The largest footprint is for food, 3.1 ha per person

per

year.

Table- II: Ecological footprint of institutional campus for the academic year 2016-2017

\begin{tabular}{|l|l|l|l|l|}
\hline Sl No. & Component & $\begin{array}{l}\text { Total Footprint } \\
(\mathrm{Ha})\end{array}$ & Population Considered & $\begin{array}{l}\text { Per Capita } \\
\text { Footprint (Ha) }\end{array}$ \\
\hline 1 & Energy & 527 & 10000 & 0.0527 \\
\hline 2 & Transportation & 75 & 1500 & 0.0500 \\
\hline 3 & Food & 30000 & 10000 & 3.0000 \\
\hline 4 & Water & 7.2 & 10000 & 0.00072 \\
\hline 5 & Campus area & 6.87 & 10000 & 0.000687 \\
\hline & Total & $30,616.07$ & 10000 & 3.104 \\
\hline
\end{tabular}

This high value is due to the relatively high usage of pasture-based and processed foods like milk and ice cream.

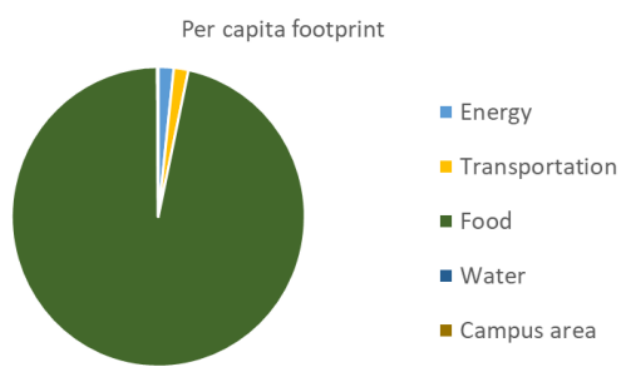

Fig. 2. Per Capita Footprint This indicates that the increasing use of processed food in our country with its associated plastic and paper use for packing

and marketing is likely to become a serious challenge to sustainability of our resources.

It should be kept in mind that other measures such as use of goods (leather, plastics, medicine, books etc.), services (postal, telephone, entertainment) etc. and waste (paper, plastics, metals etc.) have not been accounted for in this study. These may increase the footprint value. On the average, the ecological footprint of Educational Institution seems much less when compared to universities in the US [7-10]. This is especially relevant in the use of energy as we consume lesser energy in India. It will be interesting to find out the resultant footprint if the use of processed food is limited in the hostels.

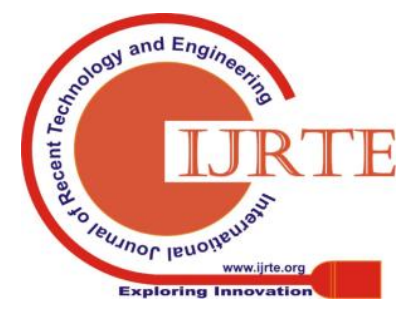


The lifestyle of students who live away from their homes and are thus susceptible to eating more junk food than healthier food may be an important factor here. We can see that to sustain the 30 ha of campus, there is a dependence on 600 ha (excluding food, goods and services and waste). Thus, even though the individual footprint is very small, this should not lead one to think that everything is fine when it comes to sustainability. With the campus growing by leaps

and bounds, it will not be far off when the resource use will overshot the resource availability. fig 2 to steer the campus life towards a more sustainable way of living. Some of these are composting to convert waste into manure; reducing consumption of paper and moving towards as much paperless administration (and exams) as possible; encouraging use of bicycles instead of cars or motorbikes inside campus; installing energy-efficient lighting; reducing use of water for lawns by planting native species instead of introduced lawns; reducing overall water usage and controlling leaks; incorporate environmental education and encourage environment-friendly activities by students; Increasing the use of solar power.

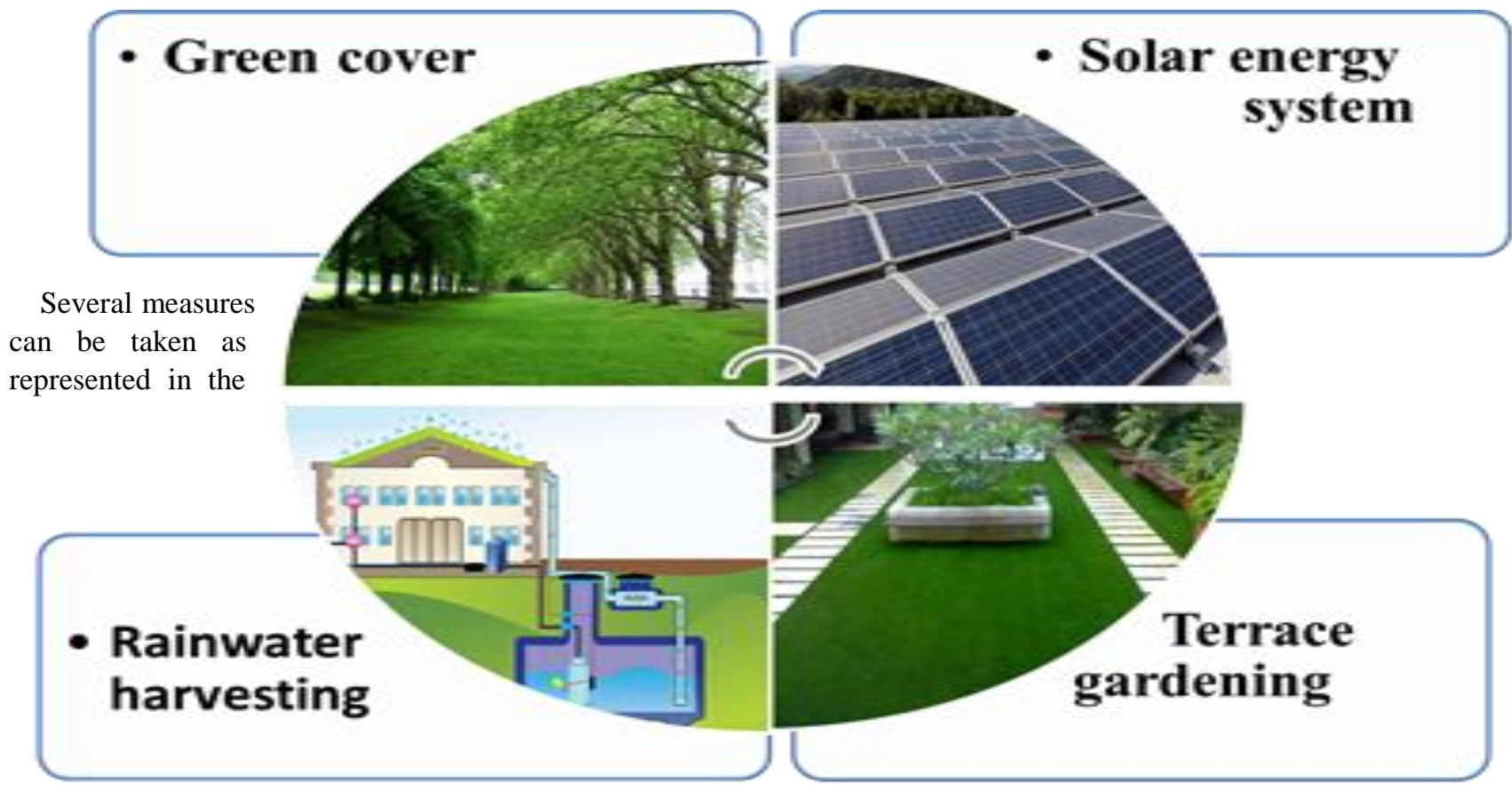

Fig. 3. Sustainable measures to make the educational campus in to self-sustainable campus (courtesy: compiled and edited by authors)

By adopting the various measures mentioned in above figure 2, campus can be made carbon negative and self-sustained green campus. It was also clear that trees are playing a significant role in reducing the carbon dioxide and increasing the ground water table by means of holding the water in its roots and it is also indirectly helping to precipitate the pollution level of the site and improve the quality of the environment.

\section{CONCLUSION}

The concept of ecological footprint as an indicator of sustainability has gained popularity in the last few years. Here, an attempt is made to calculate the ecological footprint of part of Educational Institution in South India. It is seen that energy and use of processed food account for a larger footprint. But overall, the footprint of Educational Institution seems to be lower when compared to universities with similar population in the developed countries like the USA. It will be a helpful exercise to compute the footprint for the entire University and compare it with similar places in India. The footprint as calculated in this study is not accurate; the conversion factors used are applicable to developed nations. Thus, it is imperative to consider Indian conditions and develop appropriate conversion factors so that we may get a more accurate picture of the level of sustainability in our lifestyles. Calculating the ecological footprint can be the first step towards becoming a more sustainable "green campus".

This kind of study will also help to create awareness among the public, students, and faculty and stake holders and also act as an eye opener for the other institutions to follow certain sustainable initiative to

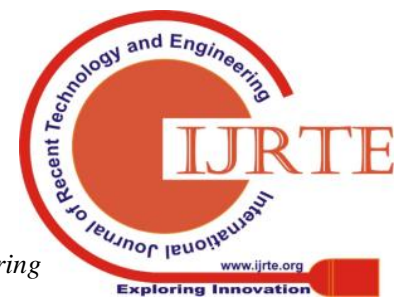


reduce the carbon emission and also the sustainable utilization of the resources. The scope of such a study is very much relevant in the current scenario of rising $\mathrm{CO}_{2}$ levels in our very own ecosystem.

\section{Conflict of Interest}

The authors declare no conflict of interest.

\section{ACKNOWLEDGMENT}

The authors are very much grateful to the educational institutional authorities of Belagavi, Karnataka for providing data to execute this research study and also authors are very much thankful to director general of National Institute of Construction Management and Research (NICMAR), Pune and the Dean School of Construction management for their continuous support and encouragement.

\section{REFERENCES}

1. Venetoulis and Lamont Hempel, "Campus ecology and sustainability: The ecological footprint of the University of Redlands", Report prepared for the University of Redlands.

2. Michael Knaus, Dirk Löhr and Bernadette O'Regan, "Valuation of ecological impacts - a regional approach using the ecological footprint concept", Environmental Impact Assessment Review, 2006, 26, p.156.

3. Conway, T.M., Dalton, C., Loo, J., Benakoun, L., "Developing ecological footprint scenarios on university campuses: a case study of the University of Toronto at Mississauga". Int. J. Sustain. High.Educ., 9, 2008, p.4-20.

4. Dawe, G.F.M., Vetter, A., Martin, S., “An overview of ecological foot printing and other tools and their application to the development of sustainability process, UK. Int. J. Sustain. High. Educ, 5, 2004, p.340-371.

5. Flint, K., "Institutional ecological footprint analysis - a case study of the University of Newcastle, Australia”. Int. J. Sustain. High. Educ., 2, 2001, p. 48-62

6. Lenzen and Shauna A. Murray, "The ecological footprint - Issues and trends", The University of Sydney, Australia, 2003,p.1-3.

7. Fiala, N., Measuring sustainability: why the ecological footprint is bad economics and bad Environmental science. Ecol.Econ., 67, 2008, p. 519-525.

8. Gottlieb, D., Kissinger, M., Vigoda-Gadot, E. and Haim, A., "Analyzing the ecological footprint at the institutional scale - The case of an Israeli high-school". Ecol. Indic., 18, 2012, p.91-97.

9. Klein-Banai, C., Theis, T.L., “An urban university's ecological footprint and the effect of climate change". Ecol. Indic., 11, 2011, p.857-860.

10. Emily P. Wright, "Ecological footprint of Colorado College", Independent Study, 2002.p.231-242.

11. Larsen, H.N., Petterson, J., Solli, C. and Hertwich, E.G., "Investigating the Carbon Footprint of a University" - The case of NTNU. J. Clean. Prod., 48, 2013, p.39-48.

12. Wiedmann, T. And J. Minx, "a definition of 'carbon footprint'. Ecological economics research trends, 1:2008. P.1-11.

13. Mathis Wackernagel, Ritik Dholakia, Diana Deumling and Dick Richardson, Redefining Progress, v 2.0, 2000.p.6-10

14. Wiedmann, T., "A first empirical comparison of energy Footprints embodied in trade" - MRIO versus PLUM.Ecological Economics ,68(7) :2009. p.1975-1990.

15. Fang,K.,R.Heijungs, and G.R.D. Snoo, "Theoretical exploration for the combination of ecological, energy, carbon, and water footprints". Ecological Indicators, 36(1): 2014. p. 508-518.

16. Divya Pandey, Jai Shanker Pandey, 2011, Carbon Footprint: Current Methods of Estimation, Environmental Monitoring and Assessment DOI, Volume 178, p.135-160.

17. Vivek Anand Asokan, 2013, Measuring sustainability of India through Ecological Footprint approach DOI: $10.13140 /$ RG.2.2.24172.p.56-64.

\section{AUTHORS PROFILE}

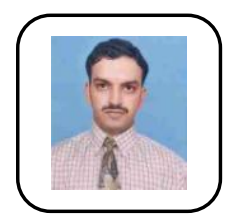

First author: Assistant Professor having more than 2 decade of teaching and 12 years of researchexperience. He published more than 35 articlesin reputed journal and published 2 text books.

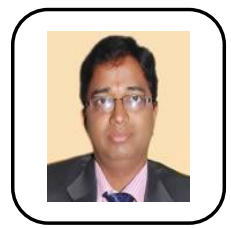

Second author: Professor having more than 4 decade of teaching and 2 years of research experience. He published more than 10 articles in reputed journal.

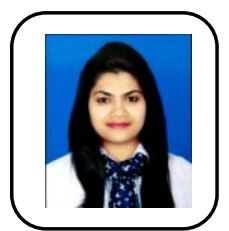

Third author, Post Graduate student in construction management at NICMAR Pune, Certified IGBC Accredited Professional.

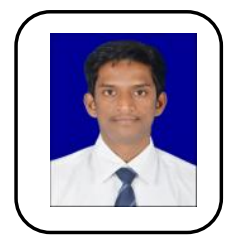

Forth author, Post Graduate student in construction management at NICMAR Pune, Certified IGBC Accredited Professional. 